\title{
Huge nasal mucosal malignant melanoma in a patient with lack of BRAF V600E mutation
}

\author{
Nasuhi Engin Aydin ${ }^{1,2}$
}

${ }^{1}$ Patoloji KLinigi, Izmir Ataturk Egitim ve Arastirma Hastanesi, Izmir, Turkey

${ }^{2}$ Tip Fakültesi, Izmir Katip Celebi Universitesi, Izmir, Turkey

\section{Correspondence to}

Professor Nasuhi Engin Aydin, nasuhiengin@gmail.com

Accepted 26 August 2016
CrossMark

To cite: Engin Aydin N. BMJ Case Rep Published online: [please include Day Month Year] doi:10.1136/ bcr-2016-217574

\section{DESCRIPTION}

The MRI of a patient having symptoms of nasal shows a huge left nasal obstructive mass $9 \mathrm{~cm}$ in dimension (figure 1) infiltrating the nearby

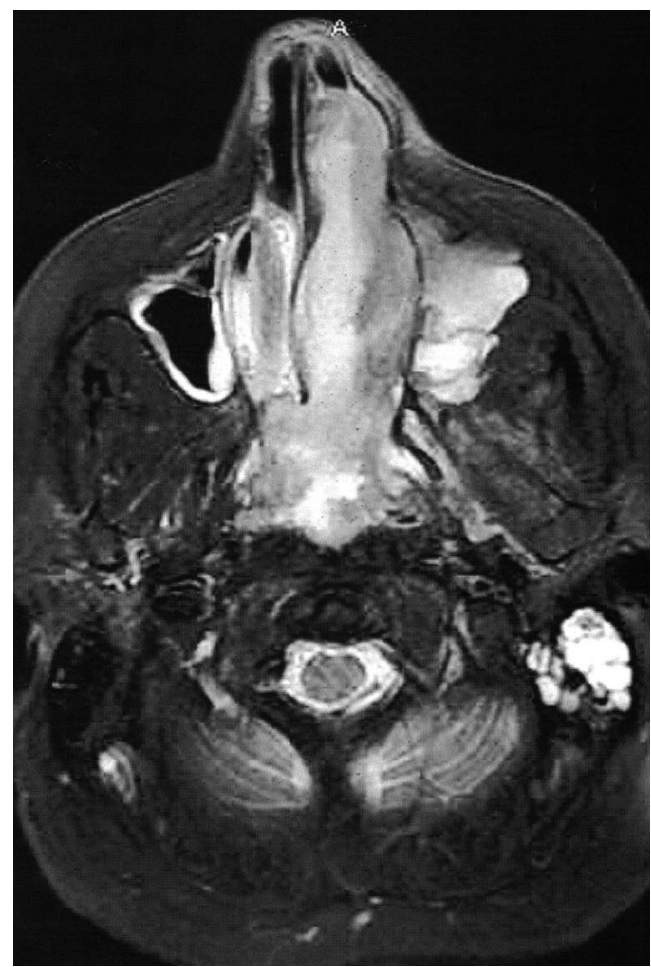

Figure 1 MRI showing a huge left nasal mass with a dimension of $9 \mathrm{~cm}$ invading the nearby anatomical structures.

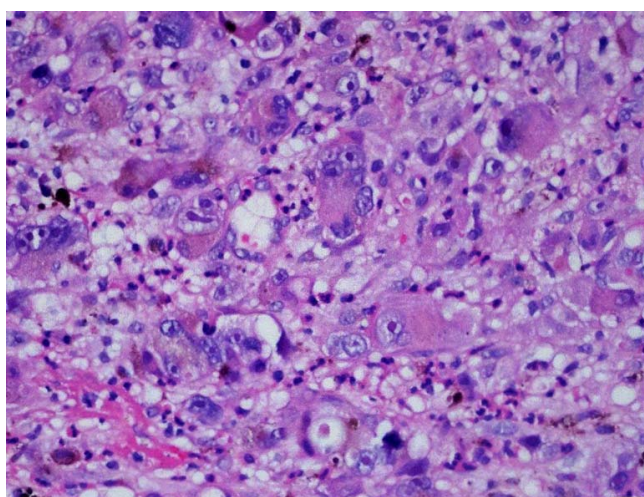

Figure 2 Diffused infiltration of the epithelioid cells with big vesicular, pleomorphic nuclei and prominent nucleoli. There are also multinucleated giant cells.

Melanin pigment can be seen on the left upper part of the section $(H \& E, \times 400)$. anatomical structures making the local stage of the malignant mass as staged T4a as per the 2013 American Joint Committee on Cancer staging system for mucosal melanomas of the head and neck. ${ }^{1}$ Biopsy revealed a highly anaplastic malignant tumour with multifocal melanin pigment formation (figure 2). The microscopic differential diagnosis was sinonasal undifferentiated carcinoma and high-grade large cell lymphomas. Melanin pigmentation in the biopsies is a clue to the diagnosis of melanoma along with positivity with S100 and HMB45 immunohistochemically. ${ }^{2}$

\section{Learning points}

- Biopsy for nasal obstructive masses is of utmost importance for early diagnosis of malignancies in this region.

- Highly anaplastic tumours in the sinonasal tract must also be evaluated for mucosal melanoma.

- Nasal melanomas lose their multimodal treatment opportunities in an advanced stage as in this case.

Acknowledgements The author would like to thank Dr Andreas Jung, Munich, Germany for his kind assistance for the molecular study of the case.

Competing interests None declared.

Patient consent Obtained.

Provenance and peer review Not commissioned; externally peer reviewed.

\section{REFERENCES}

1 National Comprehensive Cancer Network. NCCN Clinical Practice Guidelines in Oncology: head and neck cancers. V 1.2016. http:// www.nccn.org/professionals/physician_gls/pdf/head-and-neck.pdf (accessed 12 Jun 2016).

2 Murali R, Busam KJ, Barnhill RB. Melanocytic neoplasms of the mucosa. In: Barnhill RB, ed. Pathology of the melanocytic nevi and melanoma. 3rd edn. Springer: Berlin, 2014:489-508.

3 Wenig BM. Atlas of head and neck pathology. 3rd edn. Philadelphia, PA: Elsevier, 2016:211-18. 
Copyright 2016 BMJ Publishing Group. All rights reserved. For permission to reuse any of this content visit http://group.bmj.com/group/rights-licensing/permissions.

BMJ Case Report Fellows may re-use this article for personal use and teaching without any further permission.

Become a Fellow of BMJ Case Reports today and you can:

- Submit as many cases as you like

- Enjoy fast sympathetic peer review and rapid publication of accepted articles

- Access all the published articles

- Re-use any of the published material for personal use and teaching without further permission

For information on Institutional Fellowships contact consortiasales@bmjgroup.com

Visit casereports.bmj.com for more articles like this and to become a Fellow 